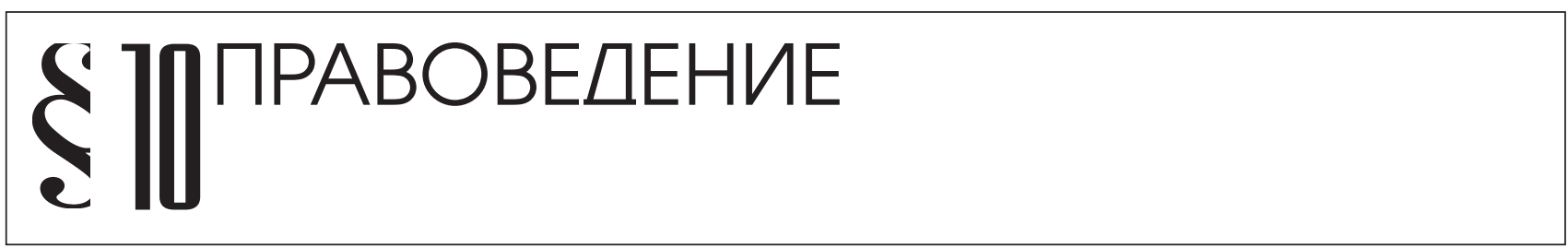

Волков А.Д.

\title{
ЮРИДИЧЕСКАЯ ПРИРОДА ГОСУДАРСТВЕННОГО СУВЕРЕНИТЕТА (ОТ АБСОЛЮТНОЙ МОНАРХИИ ДО ИДЕЙ ФЕДЕРАЛИЗМА)
}

Аннотация: В статье рассматривается происхождение понятия государственного суверенитета, организация государственной власти и ее функциональное назначение. Подробное внимание уделяется проявлению верховной власти в федеративных государствах. Исследуются политические и правовые идеи российских и зарубежных авторов. Исследуется трансформация понятия суверенитета со средних веков до наших дней. Акцентируется внимание на влиянии глобализационных процессов на суверенитет и появление федерализма. Федеральное устройство государства рассматривается во взаимосвязи с его суверенитетом. Устанавливаются критерии определения наличия суверенитета у того или иного субъекта. В процессе исследования автор применил сравнительно-правовой и аналитико-правовой анализ. Также применялись методы сопоставления и сравнения. В статье отмечается, что лишь организованный в государство народ, имеющий для реализации своих непосредственных задач и интересов собственную верховную власть, обладает настоящим суверенитетом. Только при наличии сильной верховной власти, распространяющейся на всю территорию государства, можно обеспечить государственную безопасность и создать условия для развития и прогресса населения, общества и самого государства. Abstract: The article concerns the origin of state sovereignty, organization of state government and its functional purpose. Detailed attention is paid to the manifestation of the supreme power in the federal states. The author studies political and legal ideas of Russian and foreign authors, studying the transformation of the definition of sovereignty from the middle ages to our days. The attention is paid to the influence of the globalization processes upon the sovereignty and appearance of federalism. Federal structure of the state is regarded in its relation to sovereignty. The author establishes the criteria for state sovereignty of a certain subject. In the process of studies the author applied comparative legal and analytical legal analysis. The methods of correlation and comparison were also used. It is noted in the article that it is only the people organized as a state, having its own supreme power for the implementation of its direct goals and interests, has true sovereignty. And it is only in the presence of strong supreme power throughout the territory of the state, it is possible to guarantee state security and to form conditions for the development and progress of the people, society and state itself.

Ключевые слова: суверенитет, государство, власть, верховенство, федерализм, иентрализация, децентрализачия, полномочия, безопасность, угрозы.

Keywords: sovereignty, state, power, supremacy, federalism, centralization, decentralization, competence, security, threats.

амостоятельность и независимость государства при определении и осуществлении внешней и внутренней политики, а также верховенство государственной власти внутри страны - вот, что, как правило, понимается под государственным суверенитетом. Тем самым, можно сказать, что основной качественной характеристикой государственной власти является именно суверенитет. Данная характеристика в пределах политически организованного территориального целого делает ее (власть) действительно главен- ствующей и высшей. Ведь именно суверенитет и есть важнейший атрибут государства, являющийся его основным признаком.

Суверенитет как политический и правовой феномен может рассматриваться в трех аспектах: 1) как идея, то есть некий умопостигаемый образ, взятый в его потенциально имманентной цели и возможности существования; 2) реально существующее явление, взятое в его историческом развитии; 3) юридическая конструкция, правовая форма закрепления, реально или идеально отображенная в 
DOI: $10.7256 / 1811-9018.2014 .6 .12121$

При цитировании этой статьи сноска на dоі обязательна

\section{Право и политика $6(174) \cdot 2014$}

конституционно-правовых нормах того или другого государства ${ }^{1}$.

Латинское слово «super» - выше, что дало начало выражению «suprema potestas», которое зачастую переводится юристами как «верховная власть» или «высшая власть». Понятия «верховный» - по отношению к властителю, или «высшая», когда применяется к власти, включает в себе сравнение и соотношение с другими властями и их носителями.

Вышестоящие органы и должностные лица могут подчинять себе иные уровни власти. Именно это и говорит о низшей и высшей, подчиненной и верховной властях. Такого же рода отношения создаются и между территориальными образованиями. Например, отдельные территориальные образования, входящие в состав более крупных, находятся в соподчинении и образуют иерархическую структуру властей (государство, провинция, округ). Стоящая на вершине этой лестницы власть не подчиняется никакой другой власти и потому именуется «высшей» (и по сути таковой является), или «суверенной», «верховной».

В настоящее время принято считать, что теория суверенитета была разработана и сформулирована во второй половине XVI в. французским юристом Ж. Боденом, которого справедливо называют отцом этой теории. Он определят суверенитет непосредственно как не ограниченную законами верховную власть над подданными и гражданами, абсолютную и постоянную власть государства, наивысшую власть распоряжаться ${ }^{2}$. По мнению Ж. Бодена именно такая власть выступает определяющим условием существования государства и, кроме того, является необходимым его атрибутом.

Тем самым, как политико-правовое явление - суверенитет представляет собой феномен верховенства власти, а фактическое и реальное выражение суверенитета государства и есть наличие в государстве верховной власти.

В любой стране организация государственной власти обладает присущими ей внутренними качествами единства, публичности и верховенства. Именно такой признак государственной власти, как публичность, связывает ее с непосредственными интересами всего общественно-политического организма и непосредственно объединяет их путем выражения в той или иной мере

\footnotetext{
${ }^{1}$ Грачев Н. И. Мифология и суверенитет: верховная власть сквозь призму сакральных традиций // Право и жизнь: независимый научно-популярный журнал. - 2002, - № 49 (6). - С. 13.

${ }^{2}$ Боден Ж.: Метод легкого познания истории. - М.: Наука, 2000. - C. $136-137$
}

общесоциальных интересов и целей, а не эгоистические интересы отдельных классов и социальных групп.

Единство - вот чем власть обладает в государственно организованном обществе. Так, власть в лице правящей общественной группы доминирующего слоя элиты, класса или всего народа, в первую очередь интересы и волю которого она выражает, всегда имеет единый социальный источник.

Кроме того, государственная власть, организованная с целью исполнения своего функционального назначения, всегда будет иметь единые направления деятельности, задачи и цели, определяемые целями и задачами, стоящими перед государством, страной и населяющим ее народом. Отсюда выводится единство организационно-правовой деятельности и построения государственного аппарата как материального носителя власти в государстве.

Внутренняя организация и иерархичность строения любого социального организма является его определенной степенью единства. Наличие внутренней организации в деятельности и построении власти означает ее структурированность и иерархичность. Изначально власть не может не быть структурированной и организованной, тем самым, она не может не иметь своего последнего (конечного), предельного (крайнего) высшего носителя (центра). Именно он (высший носитель) концентрирует власть в своих руках и после распространяет ее по структурным уровням, распределяя властные функции и полномочия.

Таким образом, мы видим находящиеся в определенном соподчинении в системе государственной власти любого государства различные органы, подразделения, звенья, уровни, выполняющие различные публичные функции и обладающие разным уровнем полномочий по их реализации. Так, чем выше уровень осуществления предоставленных функций, тем шире объем полномочий у лица или органа, которое призвано их исполнять, а, тем самым, его деятельность будет носить более значимый публичный характер.

Признак единства государственной власти и признак публичности являются непосредственно связанными с явлением иерархии. Так, говоря о суверенитете, путем «привязывания» его к государственной власти, речь идет, прежде всего, о самой государственной власти и только в одном единственном смысле - как о верховной власти.

Тем самым, суверенитет при юридическом подходе «является понятием, выражающим иерархичность отношений между официальными носителями власти в государстве и утверждающим, что в этих 
отношениях должна быть некая высшая точка, некий высший центр действия, обладающий способностью последних решений» ${ }^{3}$. Иными словами, носитель суверенитета и высшего центра действия, непосредственно верховной властью, - является тот субъект властной деятельности, который обладает правом (полномочиями) на решения окончательного характера по наиболее значимым и важным вопросам государства и общества. Эти «последние» решения - есть монополия властного субъекта.

В этом и состоит сущность суверенитета, который, по мысли К. Шмитта, «юридически должен правильно определяться не как властная монополия или монополия принуждения, но как монополия решения», ${ }^{4}$ последнего и исключительного, не подлежащего пересмотру, обжалованию или оспариванию.

Государство не может существовать без суверенитета, выраженного проявлением верховной власти. В нем не может не быть так называемого суверена - конечного и предельного носителя верховной власти. Тем самым, не обладающий суверенитетом государственный союз, не может рассматриваться как независимое самостоятельное государство.

Если определяющее (последнее) решение от имени государства выносит кто-то другой, если такого Верховного носителя (суверена) нет, то это образование уже нельзя назвать государством, это скорее область или провинция, входящая в сферу властных суверенных отношений как несамостоятельный член - как один из субъектов. Отличительный и самый существенный признак государства, без которого оно просто не может существовать как независимое и самостоятельное политическое целое - это наличие суверенитета именно как верховной власти. Абсолютный характер и постоянство и есть два основных признака верховной власти.

Стоит отметить, что постоянство верховной власти не имеет временного критерия, оно определяется как непроизводность и независимость этой власти в границах социальных отношений от всякого иного источника на земле, кроме самого ее обладателя.

При рассмотрении суверенитета в мифологическом плане, то суверенен один лишь Бог, обладающий надмирской властью, превыше которой ничего нет и не может быть, ведь Бог превыше правителя «земного». Тем самым, именно Бог является абсолют-

\footnotetext{
${ }^{3}$ Алексеев Н. Н. Русский народ и государство. - М.: Аграф, 2002. - C. 540.

${ }^{4}$ Шмитт К. Политическая теология: сборник. - М.: КАНОНпресс-Ц., 2000. - С. 26.
}

ным сувереном всех мировых государств, верховная власть которых подчинена «требованиям морального порядка» и «закону Бога и природы». Однако земной властелин - божественный представитель на земле, через которого осуществляется управление свыше. Аналогичный подход к происхождению верховной власти можно найти в любом обществе, основанном на религиозной традиции ${ }^{5}$.

Однако ряд авторов также приписывают качества независимости и непроизводности и другим формам проявления верховной власти - демократической и аристократической. Суверенитет имманентен самой непосредственной идее государства, являясь при этом его необходимым признаком, независимо от формы проявления суверенитета. Так, меняя свои формы, настоящая и истинная верховная власть никогда не меняет свою сущность и назначение, политико-правовую природу и изначальную идею ${ }^{6}$.

По мнению Л. Тихомирова, верховная власть как «единственный представитель всей нации» и «выразитель ее верховного идеала», по существу своему «универсальна, ... заключает в себе все проявления власти» и силы, какие порождаются социальной жизнью, и все они находятся под ее верховенством, вне зависимости от формы правления ${ }^{7}$.

Тем самым, основополагающей идеей верховной власти, а значит и суверенитета, является концентрация всех властных полномочий и функций в руках его единственного держателя, который осуществляет полновластие. Б. Чичерин в своей работе писал, что «Совокупность принадлежащих Верховной Власти прав есть полновластие, как внутреннее, так и внешнее», «Юридически она ничем не ограничена; она может делать все, что считает нужным для общего блага... Эта власть в юридической области полная и безусловная. Это полнота власти называется иногда абсолютизмом государства... В самодержавных правлениях Монарх потому имеет неограниченную власть, что он единственный представитель государства как целого союза. Но и во всяком другом образе правления Верховная Власть точно так же неограниченна. Это полновластие не составляет принадлежности того или иного образа правления; оно существует при всяком образе правления, ибо

\footnotetext{
${ }_{5}^{5}$ Грачев Н. И. Мифология и суверенитет: верховная власть сквозь призму сакральных традиций // Право и жизнь: независимый научно-популярный журнал. - 2002, - № 49 (6). - С. 24.

${ }^{6}$ Руссо Ж. - Ж. Трактаты. - М, 1969. - С.168-169.

7 Тихомиров Л. А. Монархическая государственность. - СПб., 1992. - C. 501, 544.
} 
DOI: $10.7256 / 1811-9018.2014 .6 .12121$

При цитировании этой статьи сноска на dоі обязательна

\section{Право и политика $6(174) \cdot 2014$}

неразлучно с самим существом государства как верховного союза» ${ }^{8}$.

Следовательно, во всех государствах природа и существо верховной власти одинакова, она везде неограниченна юридически, полновластна и непроизводна, тем самым, абсолютна. Возможное отличие заключается в том, что в одних государствах верховным органом государственной власти является коллегия, например, в республиках, в других это может быть монарх - отдельное лицо; полнота верховной власти и полномочий, тем самым, может распределяться между собой.

Если рассматривать ситуации, когда необходимо, чтобы в качестве последней инстанции выступали различные звенья или только один непосредственный орган, то для этого необходимо будет учитывать ряд обстоятельств внутреннего и внешнего характера, различных обычаев и условий, места и времени, даже традиций государствообразующего народа. Важно осознавать то, что в существе выполняемых верховной властью полномочий и функций принципиальных различий нет, что означает ее единую природу, независимо от различных государственных форм организационного проявления.

Идея полновластия - и есть основа классической теории суверенитета, что подтверждается доктриной верховенства британского Парламента, которую разработали английские правоведы Дайси и Блэкстон.

Согласно данной доктрине Парламент, в юридическом плане под ним понимается монарх, палата общин и палата лордов, что также обозначается выражением «король в Парламенте», обладает неограниченной и верховной властью издавать, объяснять, расширять, утверждать, возобновлять, ограничивать и отменять законы, относящиеся к всевозможным областям. «Парламент есть то учреждение, которому конституцией вверена деспотическая, неограниченная власть, которая в каждом государстве должна находиться в чьих-нибудь руках». Поэтому «он может регулировать или совсем изменить порядок престолонаследия, переменить господствующую религию страны, изменить или пересоздать устройство королевства и самого парламента. Он может сделать все, что не невозможно физически»?.

По мнению сторонников классической концепции суверенитета, верховная власть не может иметь проч-

\footnotetext{
8 Чичерин Б. Н. Общее государственное право. - М.: Зерцало, 2006. - C. 66.

9 Дайси А. В. Основы государственного права Англии. - М., 1905. - C. 45,47-48.
}

ных юридических рамок. Она волей-неволей вынуждена выходить за них, действовать исходя из принципов целесообразности, а иногда и необходимости, примеряясь к сложившимся условиям, обстоятельствам и собственным возможностям. Она обязана зачастую оперативно реагировать на сложившуюся ситуацию, вводить новые нормы, менять устоявшиеся правила или действовать по усмотрению в случае экстремальной ситуации, и тогда право отходит на задний план.

Но для того чтобы принимать, изменять, отменять законы, приостанавливать действие конституции, то есть всего существующего правопорядка, необходимо обладать принципиально неограниченными полномочиями. Конституция государства и законодательство ориентированы на нормальную, стабильную ситуацию. В такой ситуации неограниченность верховной власти отнюдь не означает ее произвольности. Она вполне соединима с закономерностью и правовым характером деятельности высших органов власти: принятые ими законы ставят также их самих в определенные юридические рамки. Исходя из этого, Г. Еллинеком была разработана теория самоограничения верховной власти, в соответствии с которой верховная власть ограничивается правовыми нормами ею самой установленными. «Государство юридически ограничено самим фактом существования порядка», - писал он. Но тем самым, издавая закон, оно «юридически связывает не только индивидов, но и свою собственную деятельность». «В его власти - как фактической, так и юридической придать тот или другой характер правопорядку, но не решить вопрос о его существовании» ${ }^{10}$.

Однако юридическая неограниченность верховной власти не означает ее фактическую неограниченность и произвольность. По словам Н. М. Коркунова, верховная власть ограничена исторической обстановкой, законами природы, «пределами физической возможности и бытовыми условиями» ${ }^{11}$.

Принимая во внимание свои возможности относительно тех или иных возникших обстоятельств она (власть) выбирает те или иные решения, которые, как мы видим, не являются произволом. Неограниченности верховной власти в абсолютном фактическом смысле никогда и нигде не существовало, более того - и не может существовать, так как «властная всемогущность» даже самой авторитарной или автократичной и есть фикция с фактической точки зрения. Поэтому

\footnotetext{
${ }^{10}$ Еллинек Г., Общее учение о государстве. - СПб.: Юридический центр Пресс, 2004, - С. 459,460.

${ }^{11}$ Коркунов Н. М. Русское государственное право. Т.2. - С. 324.
} 
с фактической точки зрения понятие неограниченной власти весьма условно. Не зависящее ни от каких-либо внешних воздействий абсолютное положение верховной власти государства невозможно. «Безгранична суверенная власть только в том смысле, что никакая другая власть юридически не может воспрепятствовать ей в изменении ее собственного правопорядка» ${ }^{12}$.

Тем самым, с позиции классической теории суверенитета государственный суверенитет выступает как внешне постоянная, непроизводная, неограниченная юридически верховная власть государства, которая концентрирует в своих руках монопольное право на принятие решений окончательного характера по всем важным вопросам общенационального (общегосударственного) значения ${ }^{13}$.

Если говорить о внутреннем источнике государственного суверенитета, то им будет выступать не только всеобщее благо народа, но и сам народ как его носитель. Именно он выделяет из своих рядов конкретных дееспособных держателей (носителей) власти и наделяет их необходимыми прерогативами и полномочиями путем определенных правовых и моральных механизмов. Правовое содержание и юридическая сущность государственного суверенитета заключаются, прежде всего, в праве верховной власти на монопольное и самостоятельное принятие решений окончательного и всеобщего характера по вопросам национальных (государственных) интересов, что делает государство независимым на внутренней и международной арене.

По своему существу верховная власть есть власть универсальная - это ее основополагающая идея. Она включает в себе все проявления государственной власти, ей принадлежит полный объем властных полномочий по реализации государственных функций и задач, часть которых она может делегировать из центра нижестоящим подчиненным субъектам (звеньям, органам и уровням государственного аппарата), являющимся производными от нее.

Вместе с тем, необходимо отметить, что вопросы наиболее важного характера, которые касаются жизнедеятельности и существования всего общества, являющиеся принципиальными для всего государства в целом, остаются в непосредственном ведении верховной власти. Данные вопросы являются основополагающими и находятся в исключительной верховной компетенции,

\footnotetext{
${ }^{12}$ Еллинек Г. Общее учение о государстве. - С. 464.

${ }^{13}$ Грачев Н. И. Верховная Власть и народ в контексте соотношения «внешнего» и «внутреннего» аспектов суверенитета государства //Философия права. - 2006. - С. 17.
}

ядром и важнейшей частью которой будут суверенные права. Это есть основа правового статуса государства, без которого оно не сможет существовать как самостоятельное и независимое (суверенное) образование.

Тем самым, суверенные права являются юридическим фундаментом конструкции суверенитета, именно они обеспечивают наличие суверенитета, его абсолютности и независимости, а также степень его целостности.

Многие авторы с момента разработки концепции суверенитета Ж. Боденом составляли свои представления суверенных полномочий, которые были бы присущи исключительно верховной власти, или выделяли из них наиболее значительные и важные. Как правило, с суверенными полномочиями отождествляются решения следующих вопросов: определение территориального устройства государства, а также статуса его субъектов (региональных составляющих); организация аппаратов власти и управления в государстве; безопасность и оборона государства; объявление войны и заключение мира; установление и изменение конституционного порядка в государстве; введение и прекращение чрезвычайного положения, прочих режимов временного ограничения прав и свобод граждан; заключение и расторжение международных договоров; определение способов, целей и средств наказания и принуждения; денежная эмиссия и принятие бюджета; установление финансовой и налоговой системы.

Тем самым, компетенции высших государственных органов и самого государства - есть квинтэссенция суверенных прав, которые образуют саму сущность верховной власти. Именно они являются тем самым признаком, определяющим субъекты, которые являются ее носителями и обладателями непосредственно верховной властью.

Таким образом, по принадлежности суверенных полномочий к каким-либо государственным звеньям или органам определяется его форма правления, характер и вид которой напрямую зависит от организации государственной верховной власти, а также правовое положение и структура высших государственных властных органов. Отношение высших органов государства с населением и друг с другом, их внутренняя структура и порядок формирования является организацией верховной государственной власти.

Понятие формы правления сообщает нам о структуре верховной государственной власти, ее устройстве и строении, а также о ее порядке осуществления возложенных функций (деятельности) при решении вопросов общегосударственного значения. Можно сказать, 
DOI: $10.7256 / 1811-9018.2014 .6 .12121$

При цитировании этой статьи сноска на dоі обязательна

\section{Право и политика $6(174) \cdot 2014$}

что авторы, связывающие суверенитет государства с формой правления, абсолютно правы. Ведь так можно получить ответ на многие вопросы относительно главы государства и принадлежности суверенитета, обладания властными прерогативами и суверенными правами в отношении всего населения и территории, на котором оно проживает.

Как установили древнегреческие мыслители - основа верховной власти базируется на одном из принципов: демократия, аристократия и монархия. Значение будет иметь право безапелляционного последнего и окончательного решения: в современном мире, как правило, весь народ, который реализует это право через избирательную систему; олигархия или аристократия, как активная правящая элита и политическое меньшинство; или один единственный человек - монарх, правящий на свое усмотрение. При данном разнообразии форм правлений не возникает сложностей при определении социально-политического элемента, который в действительности имеет способность и, самое главное, обладает правом на принятие обязательных для всех окончательных решений общегосударственного характера.

После эпохи буржуазных революций именно народ повсеместно становится первоисточником государственной верховной власти, осуществляя ее совместно и в свое личное благо. Именно народ, воплощая свою волю и идеалы, издает законы - это результат его свободной деятельности. Тем самым, вводится такое понятие, как «народный суверенитет», так как народ и есть суверен - он представляет сам себя, кроме того, передаваться (делегироваться) может исключительно власть, а не сама воля народа. Народный суверенитет неделим и неотчуждаем, а его законодательная воля должна быть принята всеми, только после этого закон можно считать легитимным и всеобщим. В любой момент предшествующий закон может быть изменен волей народа, который сам вправе распоряжаться своей властью.

В свою очередь, Г. Гегель, говоря о народном суверенитете, вкладывает в него следующий смысл: «народ вообще является по отношению к внешнему миру самостоятельным и составляет собственное государство» ${ }^{14}$, то есть он имеет свое верховное правительство или правителя в качестве последней инстанции принятия властных решений.

Вместе с тем, необходимо отметить, что верховная власть до появления федеративных государств представляла собой единый и определенный уровень

${ }^{14}$ Гегель Г. В. Ф. Философия права. - М.: Мысль, 1990. - С. 320. принятия решений общегосударственного характера, являясь высшим властным центром, концентрирующим все полномочия суверенного значения в своих руках, и находясь на верхушке государственной властной пирамиды. Появление на мировой карте в XVIII-XIX вв. федеративных государств вызвало сомнения в исключительности и абсолютности подобной организации верховной власти, а также и саму концепцию классического государственного суверенитета, которая в результате подверглась серьезной корректировке.

Возникла идея федерализма как противопоставление абсолютной монархической власти, а затем с дальнейшим развитием капитализма появляется необходимость в новой политической организации государств - изменении политико-территориальной формы, тем самым, монархическая государственность с централизованной властью с развитием буржуазных отношений стала неэффективной. Кроме того, препятствием стал принцип «абсолютного суверенитета», который мешал формированию капиталистического общества, построенного на свободной экономике и свободном предпринимательстве.

Буржуазное общество нуждалось решения вопросов территориального устройства исходя из появившихся экономических и производственных возможностей, что требовало изменений в организации государственной власти, в ее политико-правовых формах. Все эти факторы требовали децентрализации государственной власти и предоставления политической и экономической свободы регионам, что стало причиной возникновения новых проблем. Ведь расширение автономности территориальных единиц напрямую приводило к нарушению целостности государства, вступая в противоречие с принципами государственного суверенитета.

Таким образом, встал вопрос о гармоничном сочетании права на самоопределение регионов с одной стороны и государственного суверенитета с другой стороны, а также основополагающих принципов централизации и децентрализации властных полномочий, что привело к возникновению теории федерализма. Начинается осмысление федерализма с целью выяснения его основных понятий, касающихся государственного суверенитета: полномочий и компетенций, политико-правового статуса федерации и ее составных частей.

Так, вскоре были сформулированы три точки зрения, согласно которым: только федерация в целом могла обладать суверенитетом; субъекты федерации обладают суверенитетом, особенно если они наделены конституцией правом свободного выхода из состава 
федерации (союза); третий подход делил суверенитет между субъектами федерации и федерацией в целом, а также закреплялась невозможность одностороннего изменения установленного порядка.

Опыт первых федераций показал несостоятельность концепций, поддерживающих идеи делимого суверенитета и приоритетных прав субъектов федерации. В своей работе Г. Эро отмечает, что «некоторые конституционные тексты и теоретики утверждают, что объединившиеся в союз государства сохраняют часть суверенитета... Суверенитет в его специфическом смысле «наивысшей силы» или неустранимого принуждения» может находиться предположительно лишь на одном уровне, в данном случае на уровне федерации» $»^{15}$.

В обществах, где достигнуты передовые рубежи индустриализации и демократизации, появляются со стороны новых социальных групп требования о децентрализации власти. Федерализм для них является разумным решением с целью установления справедливого порядка. Так, выделяется пять социальных групп: локальную; региональную; национальную; национально-культурную и всеобщую мировую общность. Кроме того, считается, что идея федерализма несет в себе нечто большее, чем особая форма децентрализации: «...федерализм есть лишь тогда, когда несколько политических сообществ сосуществуют вместе и взаимодействуют как самостоятельные целые, объединенные в общую структуру, обладающую определенной самостоятельностью» ${ }^{16}$.

К середине XX в. на мировой арене происходит ряд изменений и событий: послевоенные проекты перестройки западноевропейских государств, распад колониальной системы, обострение межнациональных отношений в Испании и Великобритании, что превратило проблему развития федерализма в одну из самых актуальных. Ученые начинают разрабатывать подходы и отличительные признаки возможных государственных устройств, подробно изучают идеи федеративных и конфедеративных государств.

Так, изначально выделялись следующие отличительные признаки федерации: наличие двух уровней конституционной власти - центральной власти и субъектов. При конфедерации у самого союза конституционной власти нет, она принадлежит каждому из его членов; волеизъявление населения происходит совместно с волей членов федерации. При конфеде-

\footnotetext{
${ }^{15}$ Федерализм: Энциклопедический словарь. М., 1997. С. 247.

${ }^{16}$ Там же. С. 248.
}

рации представительство народа отсутствует; власть субъектов федерации не может быть ограничена центральной, если она не противоречит конституционному законодательству федерации.

Критерий взаимодействия разных уровней власти стал основной при разработке концепций идей федеративного государства. С течением времени появлялись и утвердились основные взгляды на взаимоотношение между разными уровнями властей.

Решения общефедеральных органов обязательны для всех субъектов федерации, в соответствии с ними строится вся их политика - такова «централистская» концепция, где сильная власть центра осуществляет управлением всей федерации.

Концепция «кооперативного» федерализма базируется на идее создания общества путем заключения договора и соглашений, где иерархия будет исключена, а вместо этого введена солидарная ответственность. Все значимые решения принимаются при согласовании членов союза. Можно сказать, что действует принцип «максимум согласия - минимум принуждения».

В современных условиях развивается «координационная» концепция, согласно которой между двумя правительствами происходит сотрудничество и одновременно с этим борьба по всем значимым вопросам и предметам ведения. Однако не смотря на это центральная власть осуществляет четкую координацию при решении внутренних и внешних вопросов государственного значения.

Ранее используемая «договорная» концепция, согласно которой федерация представляет собой союз государств, предполагала передачу центральному правительству определенных прав для осуществления управленческой функции. Иные права могут передаваться только при заключении нового договора с субъектами.

Дуалистическая концепция предполагает соблюдения принципа самостоятельности федерального центра и субъектов, входящих в федерацию, сферы ответственности между правительствами четко разделены, кроме того, признается разделение суверенитета, параллельно функционирует два уровня власти.

В 1941 г. возникла концепция «глобального» федерализма, под которой понимается процесс по организации мирового союза государств. Одно глобальное государство, включающее в себя ячейки из других вошедших государств, будет управляться мировым правительством. Основные принципы такого государства - интеграция, кооперация, субсидиарность. Однако данная концепция признана 
DOI: $10.7256 / 1811-9018.2014 .6 .12121$

При цитировании этой статьи сноска на doi обязательна

\section{Право и политика $6(174) \cdot 2014$}

утопической и неосуществимой на данный период развития человечества.

Продолжая вышесказанное, нельзя полностью отрицать то, что на становление и развитие федеральных отношений в различных странах огромное влияние оказывают процессы современной глобализации. Превращение в федерацию Европейского союза, активная передача местному самоуправлению полномочий от центральной власти в Великобритании федерализация Бельгии, Италии, Испании - все это яркий пример, подтверждающий процесс мировой глобализации. Тут уместно привести слова А. Захарова, отмечающего, что «чем более передовой в экономическом, политическом, гражданском отношении является та или иная страна, тем сильнее она тяготеет к федералистским экспериментам» ${ }^{17}$.

Два фактора стимулируют этот процесс: давление внешнего характера, когда приходится жертвовать частью своего суверенитета, чтобы на мировой арене поддерживать свою конкурентоспособность, и второй фактор внутреннего давления, который заключается в угрозе унификации для малых народов и культур, что вынуждает входить в мировое сообщество с целью сохранения своей самобытности (при условии, что это сообщество может обеспечить подобное).

Таким образом, заключает А. Захаров, федерализация современных индустриальных стран имеет два измерения. С одной стороны, на внешнеполитическом уровне эта часть мира заметно тяготеет к координации усилий в дипломатии, экономике, оборонной политике, широкому использованию федералистского по сути принципа консенсуса. С другой стороны, в западных социумах продолжаются процессы обособления этнических и культурных образований ${ }^{18}$.

Вышеназванные концепции скорее ориентированы на западные ценности и правовые системы, поэтому в российской действительности их реализация представляется проблематичной без учета наших политико-исторических особенностей. Известный российский юрист И. Ильин неоднократно в своих работах отмечал это, после чего синтезировал западный опыт государственного строительства и предпринял попытку интегрировать его в соответствии с русскими особенностями, традициями и условиями.

Так, И. Ильин формирует свою концепцию российского федерализма, в котором видит федерацию

17 Захаров А. А. Федерализм и глобализация // Полис. 2002. № 6. C. 117.

${ }^{18}$ Там же. С. 117. как «союз государств, основанный на договоре и учреждающий их законное, упорядоченное единение», он отмечает, что «...федерация возможна только там, где имеется налицо несколько самостоятельных государств, стремящихся к объединению. Федерация отправляется от множества (или, по крайней мере, от двоицы) и идет к единению и единству. Это есть процесс отнюдь не центробежный, а центростремительный. Федерация не расчленяет (не дифференцирует, не разделяет, не дробит), а сочленяет (интегрирует, единит, сращивает)» ${ }^{19}$.

Таким образом, И. Ильин выделяет модель историко-теоретического возникновения федераций, которая заключается в том, что малым политически оформившимся государствам необходимо единство с подобными малыми государствами для защиты от внешних и внутренних трудностей и опасностей, что приводит к образованию единого государства. Так образовались Швейцария и Соединенные Штаты, в единую державу в 1867 г. превратилась Канада, в 1871 г. объединились 25 независимых германских государств и вольных городов, а в 1885-1886 гг. в государство под английским суверенитетом объединились 6 австралийских колоний, Новая Зеландия и острова Фиджи, образовав «Австралазию». При этом устанавливается, что сохраняют, а что теряют малые государства при объединении, то есть происходит разграничение полномочий и предметов ведения, прописываются федеральные принципы и основы.

Ильин считает, что это «типичное возникновение классического федеративного государства: снизу - вверх, от малого - к большому, от множества - к единству; это есть процесс политического срастания, т. е. целесообразное движение от разрозненности ко взаимопитающему единению» ${ }^{20}$, «идея федерализма получает помимо своего главного, объединяющего и центростремительного значения - еще и обратный оттенок: неугасшей самобытности частей, их самостоятельности в законных пределах, их органической самодеятельности в недрах большого союза» ${ }^{21}$.

Ученый также говорит о том, что это далеко не единственный способ объединения малых государств в федерацию как договорный союз. Так, история показывает нам, что возможно поглощение или сращения малых государств в единую державу, то есть происходит

\footnotetext{
${ }^{19}$ Ильин И. А. Собрание сочинений: В 10 т. Т.2. Кн.1. М., 1993. C.206.

${ }^{20}$ Там же. С. 207

${ }^{21}$ Там же. С. 208
} 
политическое, экономическое и культурное срастание в унитарное государство.

Суть федерализма заключается в территориальнополитическом единстве государства, которое допускает законодательную децентрализацию государственной власти путем осуществления разграничения полномочий и предметов ведения между федеральными органами государственной власти и органами государственной власти субъектов федерации. Вместе с тем, А. Поздняков справедливо отмечает, что «при практической реализации принципа федерализма важно избежать проявлений крайностей - жесткого унитаризма, раздробленности и абсолютизации региональных особенностей» ${ }^{22}$. Федерализм базируется на системе принципов: единая территория государства формируется из субъектов, изначально являющимися территориально обособленными единицами; распределение властной компетенции и полномочий (предметов ведения) между федерацией и ее субъектами; наделение субъектов федерации исполнительно-распорядительной и учредительной властью при осуществлении своих полномочий.

Если рассматривать социально-политические принципы федерализма, то необходимо отметить их внутреннюю связь с теорией конституционализма и философией естественного права, которая отражает за основу формирование гражданского общества, а также интеграцию разных этнических групп, объединенных государственностью под общими идеями и целями.

Принципы федерализма в социально-экономическом плане изначально реализуются во внутреннем рынке страны, стягивая материальные возможности субъектов для удовлетворения государственных потребностей внутреннего характера и внешней международной экономической торговли. Кроме того, проводится внешнеэкономическая политика центра по созданию необходимых условий для развития производственного потенциала субъектов на удовлетворение разнообразных нужд. Различные теории федерализма являются совокупностью политологических, правовых и социальных взглядов относительно сущности федерализма. Это попытки теоретического понимания отдельных сторон этого многогранного явления в определенный период развития мировой цивилизации и отдельных стран.

Тем самым, мы видим, что лишь организованный в государство народ, имеющий для реализации своих

${ }_{22}$ Поздняков А. М. Развитие федеративных отношений в Российской Федерации // Федерализм: система государственных органов и практический опыт их деятельности. М., 1998. С. 174. непосредственных задач и интересов собственную верховную власть, обладает настоящим суверенитетом. Вышеуказанные типы верховной власти могут иметь различные организационно-правовые формы ее реализации: парламентарной, суперпрезидентской, президентской и полупрезидентской (смешанной) республики; парламентарной, дуалистической и абсолютной монархии. Верховная власть при любой из этих форм правления будет выступать в качестве высшей (последней) государственной инстанции, которая обладает монопольным правом на самостоятельное принятие всеобщих и окончательных решений общегосударственной жизни по наиболее важным вопросам, что и позволяет государству быть независимым и способным защищать свои интересы внутреннего и внешнего характера. Только при наличии сильной верховной власти, распространяющейся на всю территорию государства, можно обеспечить государственную безопасность и создать условия для развития и прогресса населения, общества и самого государства.

Подводя итог, можно вывести, что содержание полновластия как основной идеи суверенитета (верховной власти) заключается в следующем:

1) вся полнота государственной власти принадлежит субъекту (субъектам) верховной власти, полномочия и функции которых без исключения охватывают всю государственную деятельность, а также служат источником полномочий других производных (и подчиненных) от нее властных структур. Кроме того, за осуществленные ими действия они несут ответственность непосредственно перед верховной властью, которая контролирует и направляют их деятельность;

2) верховная власть концентрирует в своих руках все важные государственные вопросы, предметы ведения, а также она обладает исключительным правом принятия решений по вышеназванным делам;

3) верховная власть обладает прерогативой участия во всех проявлениях государственной жизни.

\section{Библиография:}

1. Грачев Н.И. Мифология и суверенитет: верховная власть сквозь призму сакральных традиций // Право и жизнь: независимый научно-популярный журнал. - 2002,-№ 49 (6). - С. 13, 24

2. Боден Ж.: Метод легкого познания истории. - М.: Наука, 2000. - С. 136-137

3. Алексеев Н.Н. Русский народ и государство. - М.: Аграф, 2002. - С. 540. 


\section{Право и политика $6(174) \cdot 2014$}

4. Шмитт К. Политическая теология: сборник. - М.: КАНОН-пресс-Ц., 2000. - С. 26.

5. Руссо Ж. - Ж. Трактаты. - М., 1969. - С.168-169.

6. Тихомиров Л.А. Монархическая государственность. - СПб., 1992. - С. 501, 544.

7. Чичерин Б.Н. Общее государственное право. - М.: Зерцало, 2006. - С. 66.

8. Дайси А.В. Основы государственного права Англии. - М., 1905. - С. 45,47-48.

9. Еллинек Г., Общее учение о государстве. - СПб.: Юридический центр Пресс, 2004, - С. 459,460, 464.

10. Коркунов Н.М. Русское государственное право. T.2. - C. 324.

11. Грачев Н.И. Верховная Власть и народ в контексте соотношения «внешнего» и «внутреннего» аспектов суверенитета государства //Философия права. - 2006. - С. 17.

12. Гегель Г.В.Ф. Философия права. - М.: Мысль, 1990. - С. 320.

13. Щербанюк О.В. Суверенитет народа как гарантия прав и свобод человека и гражданина // NB: Вопросы права и политики. - 2013. - № 10. - С.131148. DOI: $10.7256 / 2305-9699.2013 .10 .9610$. URL: http://e-notabene.ru/lr/article_9610.html

14. Федерализм: Энциклопедический словарь. М., 1997. C. 247, 248.

15. Скриба А.С.. Перспективы балансирования во внешней политике Украины в условиях сближения с региональными интеграционными объединениями // Политика и Общество. - 2013. - № 7. C. 104-107. DOI: 10.7256/1812-8696.2013.7.8947

16. С.В. Нарутто. Понятие и границы территории субъекта Российской Федерации // Национальная безопасность / nota bene. - 2012. - № 6. - C. 104-107.

17. В. П. Торукало. Федерализм и субъектность современной России // Политика и Общество. - 2012. - № 4. - С. 104-107.

18. И. П. Антонов. Формирование и развитие концепции международного права в немецкой юридической науке // Международное право и международные организации / International Law and International Organizations. - 2012. - № 1. C. 104-107.

19. Булаков О.Н., Прудников А.С.. Суверенитет представительной власти // Административное и муниципальное право. - 2011. - № 11. - С. 104-107.

20. Захаров А. А. Федерализм и глобализация // Полис. 2002. № 6. С. 117.

21. Ильин И.А. Собрание сочинений: В 10 т. Т.2. Кн.1. M., 1993. C.206, 207, 208.
22. Поздняков А. М. Развитие федеративных отношений в Российской Федерации // Федерализм: система государственных органов и практический опыт их деятельности. М., 1998. С. 174.

23. Р.Н. Пархоменко. Ю. Хабермас о понятии идеи свободы // Политика и Общество. - 2013. - № 5. C. 104-107. DOI: 10.7256/1812-8696.2013.05.13

24. В.Л. Бунчук. Становление и эволюция федеративной модели в современной России // Национальная безопасность / nota bene. - 2013. - № 1. - C. 104-107. DOI: $10.7256 / 2073-8560.2013 .01 .8$

25. Р.К. Искужин. Опыт советского федерализма в государственном строительстве Российской Федерации // Политика и Общество. - 2012. - № 12. - С. 104-107.

26. И. П. Антонов. Теория государственного суверенитета в международном праве (концептуальный подход юристов ФРГ). // Международное право и международные организации / International Law and International Organizations. - 2011. - № 4. C. $104-107$

27. Борисенков А.А. Политическая власть - политическая субстанция // NB: Проблемы общества и политики. -2013. -6. - С. 193 -217. DOI: 10.7256/23060158.2013.6.806. URL: http://www.e-notabene.ru/pr/ article_806.html

28. Гончаров В.В. Роль принципа централизма и децентрализации в организации и деятельности государственного аппарата в Российской Федерации // NB: Экономика, тренды и управление. - 2014. - 1. - С. 64 - 75. DOI: 10.7256/23064595.2014.1.2020. URL: http://www.e-notabene.ru/ etc/article_2020.html

29. Борисенков А.А. Современная российская конституция о власти // NB: Вопросы права и политики. - 2014. - 1. - C. 19 - 44. DOI: 10.7256/23059699.2014.1.10585. URL: http://www.e-notabene.ru/lr/ article_10585.html

30. Р.К. Искужин Опыт советского федерализма в государственном строительстве Российской Федерации // Политика и Общество. - 2012. - 12. - С. 114 - 120.

\section{References (transliteration):}

1. Grachev H.I. Mifologiya i suverenitet: verkhovnaya vlast' skvoz' prizmu sakral'nykh traditsii // Pravo i zhizn': nezavisimyi nauchno-populyarnyi zhurnal. 2002,-№ 49 (6). - S. 13, 24

2. Boden Zh.: Metod legkogo poznaniya istorii. - M.: Nauka, 2000. - S. 136-137 
DOI: $10.7256 / 1811-9018.2014 .6 .12121$

При цитировании этой статьи сноска на doi обязательна

Правоведение

3. Alekseev H.N. Russkii narod i gosudarstvo. - M.: Agraf, 2002. - S. 540.

4. Shmitt K. Politicheskaya teologiya: sbornik. - M.: KANON-press-Ts., 2000. - S. 26.

5. Russo Zh. - Zh. Traktaty. - M., 1969. - S.168-169.

6. Tikhomirov L.A. Monarkhicheskaya gosudarstvennost'. - SPb., 1992. - S. 501, 544.

7. Chicherin B.N. Obshchee gosudarstvennoe pravo. $-\mathrm{M}$.: Zertsalo, 2006. - S. 66.

8. Daisi A.V. Osnovy gosudarstvennogo prava Anglii. M., 1905. - S. 45,47-48.

9. Ellinek G., Obshchee uchenie o gosudarstve. $-\mathrm{SPb}$.: Yuridicheskii tsentr Press, 2004, - S. 459,460, 464.

10. Korkunov N.M. Russkoe gosudarstvennoe pravo. T.2. - S. 324.

11. Grachev H.I. Verkhovnaya Vlast' i narod v kontekste sootnosheniya «vneshnego» $\mathrm{i}$ «vnutrennego» aspektov suvereniteta gosudarstva//Filosofiya prava.-2006.-S. 17.

12. Gegel' G.V.F. Filosofiya prava. - M.: Mysl', 1990. S. 320 .

13. Shcherbanyuk O.V. Suverenitet naroda kak garantiya prav i svobod cheloveka i grazhdanina // NB: Voprosy prava i politiki. - 2013. - № 10. - S.131-148. DOI: 10.7256/2305-9699.2013.10.9610. URL: http://e-notabene.ru/lr/article_9610.html

14. Skriba A.S.. Perspektivy balansirovaniya vo vneshnei politike Ukrainy $\mathrm{v}$ usloviyakh sblizheniya $\mathrm{s}$ regional'nymi integratsionnymi ob"edineniyami // Politika i Obshchestvo. - 2013. - № 7. - S. 104-107. DOI: $10.7256 / 1812-8696.2013 .7 .8947$

15. S.V. Narutto. Ponyatie i granitsy territorii sub"ekta Rossiiskoi Federatsii // Natsional'naya bezopasnost' / nota bene. - 2012. - № 6. - S. 104-107.

16. V. P. Torukalo. Federalizm i sub"ektnost' sovremennoi Rossii // Politika i Obshchestvo. - 2012.-№4. -S. 104-107.

17. I. P. Antonov. Formirovanie i razvitie kontseptsii mezhdunarodnogo prava v nemetskoi yuridicheskoi nauke // Mezhdunarodnoe pravo i mezhdunarodnye organizatsii / International Law and International Organizations. 2012. - № 1. - S. 104-107.

18. Bulakov O.N., Prudnikov A.S.. Suverenitet predstavitel'noi vlasti // Administrativnoe i munitsipal'noe pravo. - 2011. - № 11. - S. 104-107.
19. Zakharov A. A. Federalizm i globalizatsiya // Polis. 2002. № 6. S. 117.

20. Il'in I.A. Sobranie sochinenii: V 10 t. T.2. Kn.1. M., 1993. S.206, 207, 208.

21. Pozdnyakov A. M. Razvitie federativnykh otnoshenii v Rossiiskoi Federatsii // Federalizm: sistema gosudarstvennykh organov i prakticheskii opyt ikh deyatel'nosti. M., 1998. S. 174.

22. R.N. Parkhomenko. Yu. Khabermas o ponyatii idei svobody // Politika i Obshchestvo. - 2013. - № 5. - S. 104-107. DOI: 10.7256/1812-8696.2013.05.13

23. V.L. Bunchuk. Stanovlenie i evolyutsiya federativnoi modeli v sovremennoi Rossii // Natsional'naya bezopasnost' / nota bene. - 2013. - № 1. - S. 104-107. DOI: 10.7256/2073-8560.2013.01.8

24. R.K. Iskuzhin. Opyt sovetskogo federalizma v gosudarstvennom stroitel'stve Rossiiskoi Federatsii // Politika i Obshchestvo. - 2012. - № 12. - S. 104-107.

25. I. P. Antonov. Teoriya gosudarstvennogo suvereniteta $\mathrm{v}$ mezhdunarodnom prave (kontseptual'nyi podkhod yuristov FRG). // Mezhdunarodnoe pravo i mezhdunarodnye organizatsii / International Law and International Organizations. - 2011. - № 4. S. 104-107

26. Borisenkov A.A. Politicheskaya vlast' - politicheskaya substantsiya // NB: Problemy obshchestva i politiki.-2013.-6. - C. 193 -217. DOI: 10.7256/23060158.2013.6.806. URL: http://www.e-notabene.ru/pr/ article_806.html

27. Goncharov V.V. Rol' printsipa tsentralizma i detsentralizatsii v organizatsii i deyatel'nosti gosudarstvennogo apparata v Rossiiskoi Federatsii // NB: Ekonomika, trendy i upravlenie. - 2014. - 1. - C. 64 - 75. DOI: 10.7256/2306-4595.2014.1.2020. URL: http://www.enotabene.ru/etc/article 2020.html

28. Borisenkov A.A. Sovremennaya rossiiskaya konstitutsiya o vlasti // NB: Voprosy prava i politiki. - 2014. - 1. - C. 19 - 44. DOI: 10.7256/23059699.2014.1.10585. URL: http://www.e-notabene.ru/ 1r/article 10585.html

29. R.K. Iskuzhin Opyt sovetskogo federalizma v gosudarstvennom stroitel'stve Rossiiskoi Federatsii // Politika i Obshchestvo. - 2012. - 12. - C. 114 - 120. 